\title{
Comparison of disease severity and ultrasonographic abdominal subcutaneous fatty tissue thickness in hirsute women
}

\section{Hirsute kadınlarda hastalık abdominal subkütanöz yağ şiddeti ile dokusu karşılaştırılması} ultrasonik

\section{Betul Tas ${ }^{1}$, Golkhan Artar ${ }^{2}$, Mehmet Oncu ${ }^{3}$, Saadet Pilten ${ }^{4}$, Murat Altuntas ${ }^{5}$}

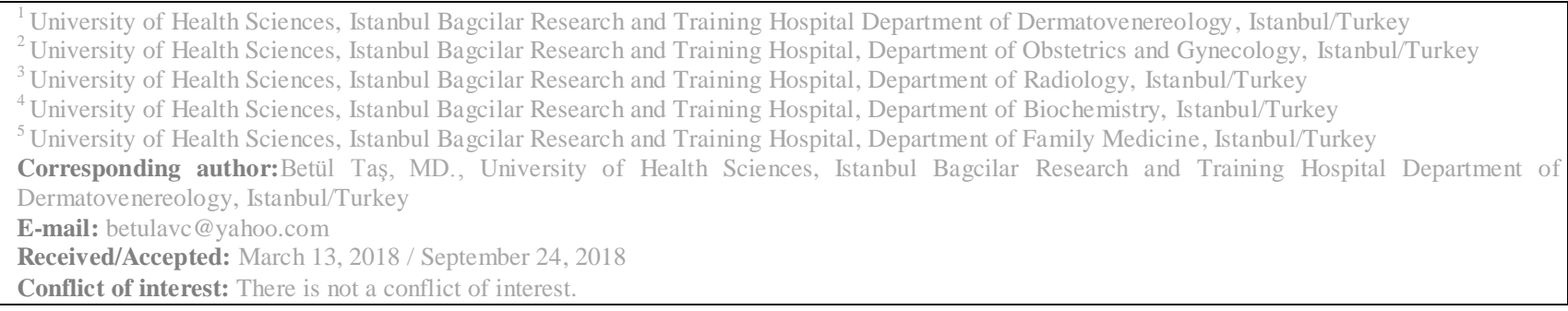

\section{SUMMARY}

Introduction: Hirsutism is a condition defining as acquired excess of hairs in the androgen-sensitive skin regions of women. It may be idiopathic, or can be resulted from metabolic or androgen-related disorders.

Objective: In order to determine of possible correlation between hirsutism scores and central obesity, comparisons of abdominal subcutaneous fatty tissue thickness, metabolic syndrome criteria and also hirsutism-related hormones, according to hirsutism stages were aimed.

Method: A prospective study was conducted on 144 women between the ages of 18-50, from October 2014 to March 2016. Beside hirsutism scores (determined by modified Ferriman-Gallway evaluation system) and subcutaneous abdominal fatty tissue thickness, metabolic syndrome criteria and hirsutism-related hormones were detected. Fatty tissue thicknes were determined by ultrasonographic measurements from 4 points around the umbilicus. Data was compared to hirsutism stages, and evaluated with Number Cruncher Statistical System 2007, as considered p $<0.05$ was significant.

Results: Only moderate and severe hirsutism groups were detected, and mean age was $24.47 \pm 7.52$ years. The most accompanying finding was polycystic ovary syndrome. Higher means for fatty tissue thickness ( $\mathrm{p}=0.0001$ for each four region), weight, body mass index, waist circumferences, systolic and diastolic blood pressures (each p=0.0001), insulin $(\mathrm{p}=0.038)$, Homeostatic Model Assesment for Insulin Resistance $(\mathrm{p}=0.033)$, triglyceride $(\mathrm{p}=0.003)$, free androgen index $(\mathrm{p}=0.004)$ and total testosterone $(\mathrm{p}=0.036)$, and lower means for high density lipoprotein cholesterol $(\mathrm{p}=0.003)$ and sex hormone binding globuline $(\mathrm{p}=0.008)$ were obtained in severe hirsutism group. Existence of 1,2 and 3 metabolic syndrome criteria, and diagnosis of metabolic syndrome were also more detected in higher-score group (each $\mathrm{p}=0.0001)$. 
Conclusions: Women with higher hirsutism scores are more likely to develop thicker subcutaneous abdominal fatty tissue and metabolic syndrome than those with moderate scores. Subcutaneous abdominal fatty tissue thicknesss may a simple metabotrophic indicator for preliminary assessment of severity of hirsutism in especially overweight women.

Keywords: Androgens, hirsutism, metabolic syndrome, subcutaneous fatty tissue, ultrasonography

ÖZET

Giriş: Hirsutizm kadınların androjene duyarlı deri bölgelerinde terminal kıllanma artışı şeklinde tarif edilen bir durumdur. İdiopatik olabileceği gibi metabolik nedenler ya da androjen yüksekliği ile ilişkili durumlar nedeniyle de ortaya çıkabilir.

Amaç: $\mathrm{Bu}$ çalışmada hirsutizm skorlarının sentral obezite ile olası korelasyonunun belirlenmesi için, abdominal subkütanöz yağ dokusu kalınlığının yanı sıra, metabolik sendrom kriterleri ve hirsutizmle ilişkili hormon değerlerinin hirsutizmin evrelerine göre karşılaștırılması amaçlanmıștır.

Yöntem: Araştırma Kasım 2014 ve Mart 2016 tarihleri arasında 18-50 yaş aralığındaki 144 kadın hasta üzerinde prospektif olarak yürütüldü. Deneklerin hirsutizm skorları (modifiye Ferriman-Gallway değerlendirme sistemi ile belirlendi) ve subkütanöz abdominal yă̆ dokusu kalınlıklarının yanı sıra, metabolik sendrom kriterleri ve hirsutizmle ilişkili hormon değerleri de tetkik edildi. Yağ dokusu kalınlığı umblikus etrafındaki 4 farklı bölgeden ultrasonografi ile ölçüldü. Elde edilen veriler hirsutizm evrelerine göre karşılaştırıldı.

Bulgular: Sadece orta dereceli ve şiddetlii hirsutizm grupları tespit edildi ve deneklerin ortalama yaşı $24.47 \pm 7.52$ idi. En fazla eşlik eden bulgu polikistik over sendromu idi. Şiddetli hirsutism grubunda diğer gruba göre, subkutan yağ doku kalınlığı (4 farklı bölgenin her biri için p=0.0001), kilo, vücut kitle indeksi, bel çevresi, sistolik ve diastolik kan basınçları (her biri için $\mathrm{p}=0.0001$, insülin $(\mathrm{p}=0.038$ ), insülin direnci homeostatik model değerlendirme indeksi $(p=0.033)$, trigliserit $(p=0.003)$, serbest androjen indeksi $(p=0.004)$ ve total testosteron $(p=0.036)$ değerleri anlaml 1 ölçüde yüksek bulundu. Aynı grupta, yüksek dansiteli lipoprotein kolesterol $(\mathrm{p}=0.003)$ ve seks hormon bağlayıcı globulin değerleri ise $(p=0.008)$ diğer gruba göre anlaml ölçüde düşüktü. 1,2 ve 3 metabolik sendrom kriteri ve metabolik sendrom tanısı şiddetli hirsutizm grubunda anlamlı ölçüde fazla saptandı.

Sonuç: Șiddetli hirsutizm grubundaki kadınlarda, daha kalın bir subkutanöz yağ dokusuna sahip olma ve metabolik sendrom geliştirme olasılı̆̆ orta şiddetli gruptakilere göre daha yüksektir. Özellikle obez hastalarda, subkütan abdominal yağ doku kalınlı̆̆ı, hirsutizm şiddetinin ön değerlendirmesinde basit bir metabotropik gösterge olabilir.

Anahtar sözcükler: Androjenler, hirsutizm, metabolik sendrom, subkütanöz yağ dokusu, ultrasonografi.

\section{INTRODUCTION}

Besides its cosmetic, sexual and psychosocial importance, subcutaneous abdominal fatty tissue is a dominant architectural, but a highly underestimated compartment of the body. It has not only ordinary biological key functions such as thermoregulation, thermoinsulation, physical buffer or energy storage, but also influences on important immune, metabolic, and even brain functions. Indeed, it has newly understood that subcutanous adipocytes have some significant functions such as cytokine and growth factor production, being a big resource for stem cells, and endocrine functions ${ }^{1}$. Since that turning point, neurobiology and molecular medicine specialists concentrated on adipotargeting studies, which clearly showed that the adipose tissue is the largest endocrine/paracrine organ producing many bioactive proteins called adipokines. Owing to these studies, certain diseases such as type 2 diabetes, atherosclerosis or metabolic syndrome (MS) have been associated with increased fatty tissue $^{2}$. Hirsutism (HR) is a multicausal androgenrelated condition. It may be idiopatic or can be resulted from androgen-releasing disorders such as polycystic ovary syndrome (PCOS), neoplasms, hyperthecosis or hyperprolactinemia. However, hyperinsulinaemic androgen excess is accepted as the most common cause of HR, in recent years. Similar to MS, it is thought that HR frequently originates from an absolute or relative excess of lipids in adipose tissue, and from associated changes in insulin sensitivity, gonadotropin secretion and ovarian androgen release $^{3}$. Lack of literature on correlations between the modified Ferriman-Galleway scores (mFGSs) and subcutaneous abdominal fatty tissue thickness (SAFTT), and also MS criteria in women with HR encouraged us to conduct this study. 


\section{MATERIAL AND METHODS}

\section{Study design and subjects}

One hundred and forty hirsute women between the ages of 18-50, years olds included in study from November 2014 to March 2015. It was conducted in our dermatology department as a prospective pilot study. The study was approved by responsible local ethical committee, and was conducted with the understanding and the consent of the human subject. The subjects who under the age of 18 and did not give consent, menopausal and pregnant women, those having known diseases which lead to HR such as congenital adrenal hyperplasia, Cushing syndrome, thyroid dysfunction, androgen secreting tumors, hypercortisolism, hyperprolactinemia, hypertekosis, who had acute disease that can lead respiratory distress, e.g., influenza (because it can prevent deep exhalation), who had known diabetes, heart, pulmonary, gastrointestinal, neurological and neoplastic diseases, who used drugs that interfere with endocrine or lipid metabolism such as sex steroids, thyroid hormones, corticosteroids, anticonvulsants, antiretrovirals, antilipidemics, who used drugs can cause hyperprolactinemia such as risperidone, haloperidol or metoclopramide, those who previously known to be MS, and who underwent any operation or had any scar in the measurement areas were excluded from study. The study was performed in accordance with the Declaration of Helsinki 2013.

\section{Data collection from clinical examinations}

After a detailed medical interview, accompanying androgen-dependent other clinical conditions including acne, seborrhea, androgenetic alopecia (AGA), acanthosis nigricans (AN), skin tag, PCOS, and changes in cycle (amenorrhea/oligomenorrhea/polymenorrhea) of subjects were examined and recorded. Later, anthropometric parameters (Weight, body mass index [BMI], waist circumcerence [WC] ), and systolic and diastolic blood pessures (SBP, DBP) of the subjects were measured. Skin findings were diagnosed clinically, and diagnosis of PCOS was made based on the Revised Criteria of Rotterdam (2003), which require the presence of at least two of the following three features: i) oligo or anovulation $\quad(<8$ spontaneous hemorrhagic episodes/year); ii) biochemical hyperandrogenemia (defined in our subjects as early follicular phase-total testosterone (TT) > $0.82 \mathrm{ng} / \mathrm{ml}$ ) or clinical manifestations of hyperandrogenemia (mFGSscore $\geq 8$ ); and iii) polycystic ovaries on ultrasound $(\geq 12$ small follicles in at least one ovary and/or ovarian volume $>10 \mathrm{~cm} 3)^{4}$. BMI was calculated as weight (kilograms) divided by height (square meters) for an estimate of obesity. The evaluation was made as underweight $=<18,5 \mathrm{~kg} / \mathrm{m} 2$, normal weight $=18.5$ to 25 , overweight $=25$ to 30 , and obese $=$ over $30^{5}$. WC was measured at the midpoint between the twelfth rib and the iliac crest ${ }^{6}$. SBP and DBP were measured following the JNC-7 guidelines $^{7}$. The diagnosis of HR was done based on clinical examination findings of subjects. Severity of disease was visually determined by the mFGS system, in which the density of terminal hairs is graded at 9 different body sites (i.e., upper lip, chin, chest, upper back, lower back, upper abdomen, lower abdomen, arm, and thigh ). According to the severity of disease, each region can take a score of 0 (absence of terminal hairs) to 4 (extensive terminal hair growth). The evaluation is made as normal, $<8$; mild, $8-15$; moderate, 1625; and severe, $>25^{8,9}$. In the examining of MS components and diagnosis of MS, National Cholesterol Education Program Adult Treatment Panel III (ATP III) criteria were used. According to the criteria, subjects who had more than 3 of the following risk factors were diagnosed with MS: levels of fasting glucose, $\geq 110 \mathrm{mg} / \mathrm{dL}$; fasting triglycerides, $\geq 150 \mathrm{mg} / \mathrm{dL} ; \mathrm{HDL},<50$ $\mathrm{mg} / \mathrm{dL}$; WC, $\geq 80 \mathrm{~cm}$; and SBP, $\geq 130 \mathrm{mmHg}$; or DBP, $\geq 85 \mathrm{mmHg}^{10,11}$.

\section{Laboratory analyzes}

Fasting blood samples for all tests including free testosterone (FT) and TT, dehydroepiandrosterone sulphate (DHEAS), androstenedione, 17-hydroxy progesterone (17-OH-PG), SHBG, prolactin, glucose, insulin, glycated hemoglobine (HbA1C), HDL and triglycerides, were taken during follicular phase (cycle days 2-8), between 8:30 and 9:00 AM in our laboratory. Serum levels of TT and prolactin were analyzed by competitive Electro Chemi Luminescence Immunoassay (Roche cobas 6000 modular system-601, Roche Diagnostics, Rotkreuz, Switzerland), using commercial kits (Roche, Rotkreuz, Switzerland). Serum FT was analyzed by Automated Enzyme Immunoassay (Grifols, Triturus, Spain) using commercial kit (Diametra, Perugia, Italy). Androstenedion levels were determined by Liquid Chromatography Mass Spectrometry (Triple mass spectrometer-LC-MS/MS, Agilent Technologies 6460C, Waldbronn, Germany) using an in-house manufactured method. DHEA-SO4 and SHBG 
were analyzed by competitive Electro Chemi Luminescence Immunoassay (Roche cobas 6000602, Roche Diagnostics, Rotkreuz, Switzerland), using commercial kit (Roche, Rotkreuz, Switzerland). 17-OH-PG was analyzed by Competitive Immunoenzymatic Colorimetric Method (Grifols Triturus system, Spain), using a commercial kit (Diametra, Italy). Plasma fasting glucose, HDL and triglyceride levels were analyzed by Automated Enzyme Immunoassay (Roche cobas 8000-702, Roche Diagnostics, Rotkreuz, Switzerland), using commercial kits (Roche, Rotkreuz, Switzerland). Serum insulin level was measured by Electro Chemi Luminiscence Immunoassay (Roche cobas 6000601, Roche Diagnostics, Rotkreuz, Switzerland), using commercial kit (Roche, Rotkreuz, Switzerland), HbA1C was analyzed by High Performance Liquid Chromatography (Arkray ADAMS 8180, Kyoto, Japan), using commercial kit (Arkray, Kyoto, Japan). Reference intervals (RI) and detection limits (DL) for the tests were as follows: $0.45-3.17 \mathrm{pg} / \mathrm{ml}$ for FT (DL: $0.2-100$ $\mathrm{pg} / \mathrm{ml}$ ), $0.06-0.82 \mathrm{ng} / \mathrm{ml}$ for TT (DL: $0.025-15$ $\mathrm{ng} / \mathrm{ml}), 65-368 \mu \mathrm{g} / \mathrm{dl}, 148-407 \mu \mathrm{g} / \mathrm{dl}, 98.8-340 \mu \mathrm{g}$ $/ \mathrm{dl}, 60.9-337 \mu \mathrm{g} / \mathrm{dl}$ and $35.4-256 \mu \mathrm{g} / \mathrm{dl}$ for DHEA-S in the age groups of 15-19, 20-24, 25$34,35-44$ and $45-54$, respectively (DL: $0,1-1000$ $\mu \mathrm{g} / \mathrm{dl}), 0.26-2.14 \mathrm{ng} / \mathrm{ml}$ and $0.13-0.82 \mathrm{ng} / \mathrm{ml}$ for Androstenedion in 18-40 and 40-100 years of women (DL: $0.1-50 \mathrm{ng} / \mathrm{ml}$ ), 26.1-110 nmol/1 for SHBG (DL: $0.350-200 \mathrm{nmol} / \mathrm{l}$ ), 4.79-23.3 ng/ml for prolactin (DL: $0.047-470 \mathrm{ng} / \mathrm{ml}$ ), $0.15-0.7$ $\mathrm{ng} / \mathrm{ml}$ for $17-\mathrm{OH}-\mathrm{PG}$ (DL: $0.2-20 \mathrm{ng} / \mathrm{ml}$ ), 74-106 $\mathrm{mg} / \mathrm{dl}$ for glucose (DL: $2-750 \mathrm{mg} / \mathrm{dl}$ ), $45-65 \mathrm{mg} / \mathrm{dl}$ for HDL (DL: $3-120 \mathrm{mg} / \mathrm{dl}$ ), $0-200 \mathrm{mg} / \mathrm{dl}$ for triglyceride (DL: $\quad 8.85-885 \mathrm{mg} / \mathrm{dl}), \quad 2.6-24.9$ $\mu \mathrm{IU} / \mathrm{ml}$ for insulin (DL: $0.2-1000 \mu \mathrm{IU} / \mathrm{ml}$ ), and 4$6 \%$ for $\mathrm{HbA1C}$ (DL:3-20\%). FAI ratio was determined by following formula: [FAI = TT(nmol/l) $x$ 100/SHBG (nmol/l)], using the following converter formula: $(1 \mathrm{ng} / \mathrm{ml}=0.314465$ $\mathrm{nmol} / \mathrm{l})$, and assesed as normal $=<5$, and high $=\geq 5$

\section{RESULTS}

One hundred and fourty four women were evaluated. Only moderate and severe HR groups were detected in study population. Mean age of the subjects was $24.47 \pm 7.52$ years. Subgroups and their distribution ratios according to the age,
[12,13]. Insulin resistance (IR)was detected by HOMA-IR, which was calculated as follows: HOMA-IR=fasting insulin $(\mathrm{mIU} / \mathrm{L}) \times$ glucose $(\mathrm{mg} / \mathrm{dl}) / 405$ [14], and evaluated as normal $=<2,5$, and high $=\geq 2,5[15]$.

\section{Ultrasonic measurement of SAFTT}

Subcutaneous fatty tissue-USG was performed on fasting subjects by the same operator using a Toshiba Aplio 300 apparatus with a $7.5 \mathrm{MHz}$ linear probe (Toshiba Medical Systems, Tokyo, Japan). SAFTT was measured from 4 different points at distances of $1 \mathrm{~cm}$ from the umbilicus (above, below, right and left). It was measured as the distance between the epidermis and the external surface of the rectus abdominis muscle at the end of the maximum exhalation [16], by applying the same probe pressure to the abdomen of subjects. Each measurement was repeated 3 times, and means of them were used for analysis. The daily intra-operator coefficient of variation for repeated measures of SAFTT in our laboratory was $0.54 \%$.

\section{Statistical analysis}

It was followed through NCSS (Number Cruncher Statistical System, Utah, USA, 2007) software package program. Standart descriptive statistics were expressed as means \pm standard deviation (SD). Categorical variables were expressed as percentages (\%). The normality assumption of the groups was checked using Kolmogorov Simirnov test. Quantitative data was compared with independent-samples t-test where their distribution was normal, whereas the Mann-Whitney $U$ non-parametric analysis was used for the comparison of group means when the distribution was not normal. Chi-square test was used to compare qualitative data. The significance of differences in means was determined using 95\% confidence intervals, and $a$ $p$ value $<0.05$ was considered as statistically significant.

marital status, HR-associated clinical findings, MS components according to the ATP III criteria, number of subjects having 0 to 4 MS criteria and MS are seen in Table 1. 
Table 1. Distributions of subgroups according to the age, marital status, HR-associated clinical findings, MS components according to the ATP III criteria, and, number of subjects having 0 to 4 MS criteria and MS.

\begin{tabular}{|c|c|c|c|}
\hline Parameters & & Total & $\%$ \\
\hline \multirow[t]{2}{*}{ Age groups } & $18-35$ & 126 & $87.50 \%$ \\
\hline & $>35$ & 18 & $12.50 \%$ \\
\hline \multirow[t]{2}{*}{ Marital status } & Unmarried & 98 & $68.06 \%$ \\
\hline & Married & 46 & $31.94 \%$ \\
\hline \multirow[t]{2}{*}{ Acne } & Absent & 19 & $13.19 \%$ \\
\hline & Present & 125 & $86.81 \%$ \\
\hline \multirow[t]{2}{*}{ Seborrhea } & Absent & 13 & $9.03 \%$ \\
\hline & Present & 131 & $90.97 \%$ \\
\hline \multirow[t]{2}{*}{ AGA } & Absent & 2 & $1.39 \%$ \\
\hline & Present & 142 & $98.61 \%$ \\
\hline \multirow[t]{2}{*}{ Amenorrhea } & Absent & 135 & $93.75 \%$ \\
\hline & Present & 9 & $6.25 \%$ \\
\hline \multirow[t]{2}{*}{ Oligomenorrhea } & Absent & 9 & $6.25 \%$ \\
\hline & Present & 135 & $93.75 \%$ \\
\hline PCOS & Present & 144 & $100.00 \%$ \\
\hline \multirow[t]{2}{*}{ Acanthosis nigricans } & Absent & 56 & $38.89 \%$ \\
\hline & Present & 88 & $61.11 \%$ \\
\hline \multirow[t]{2}{*}{ Skin tag } & Absent & 105 & $72.92 \%$ \\
\hline & Present & 39 & $27.08 \%$ \\
\hline \multirow[t]{4}{*}{ BMI (kg) } & $<18,5$ & 11 & $7.64 \%$ \\
\hline & $18,5-24,9$ & 57 & $39.58 \%$ \\
\hline & $25-29,9$ & 44 & $30.56 \%$ \\
\hline & $\geq \mathbf{3 0}$ & 32 & $22.22 \%$ \\
\hline \multirow[t]{2}{*}{ HOMA-IR } & $<2,5$ & 67 & $46.53 \%$ \\
\hline & $\geq 2,5$ & 77 & $53.47 \%$ \\
\hline \multirow[t]{2}{*}{ Glucose } & $<110$ & 118 & $81.94 \%$ \\
\hline & $\geq 110$ & 26 & $18.06 \%$ \\
\hline \multirow[t]{2}{*}{ HDL } & $<50$ & 106 & $73.61 \%$ \\
\hline & $\geq \mathbf{5 0}$ & 38 & $26.39 \%$ \\
\hline \multirow[t]{2}{*}{ Triglyceride } & $<150$ & 58 & $40.28 \%$ \\
\hline & $\geq 150$ & 86 & $59.72 \%$ \\
\hline \multirow[t]{2}{*}{$\mathrm{WC}(\mathrm{cm})$} & $<80$ & 63 & $43.75 \%$ \\
\hline & $\geq \mathbf{8 0}$ & 81 & $56.25 \%$ \\
\hline \multirow[t]{2}{*}{ SBP } & $<130$ & 62 & $43.06 \%$ \\
\hline & $\geq 130$ & 82 & $56.94 \%$ \\
\hline \multirow[t]{2}{*}{ DBP } & $<85$ & 123 & $85.42 \%$ \\
\hline & $\geq 85$ & 21 & $14.58 \%$ \\
\hline \multirow[t]{2}{*}{ SBP/DBP } & Normal & 124 & $86.11 \%$ \\
\hline & High & 20 & $13.89 \%$ \\
\hline \multirow[t]{5}{*}{ MS criteria (count) } & $\mathbf{0}$ & 12 & $8.33 \%$ \\
\hline & 1 criterion & 61 & $42.36 \%$ \\
\hline & 2 criteria & 44 & $30.56 \%$ \\
\hline & 3 criteria & 24 & $16.67 \%$ \\
\hline & 4 criteria & 3 & $2.08 \%$ \\
\hline \multirow[t]{2}{*}{ MS } & MS (-) & 117 & $81.25 \%$ \\
\hline & MS (+) & 27 & $18.75 \%$ \\
\hline
\end{tabular}


Most of the subjects ( $60-100 \%)$ had other androgen-dependent clinical conditions. The most and least accompanying findings were PCOS $(100 \%)$ and skin tag $(27.08 \%)$. The most accompanying cycle disorder was oligomenorrhea $(93.75 \%)$, whereas none of them had normal cycle or polymenorrhea. The majority of them $(39.58 \%)$ had normal BMI, whereas obesity detected in only rate of $22.22 \%$. Most subjects had normal fasting glucose (81.94\%), low HDL (73.61\%), high triglyceride (59.72\%), HOMA-IR (53.47\%), WC (56.25\%) and SBP (56.94\%) values. Comparisons of subgroup percentages and/or means of age, marital status, anthropometric values, associated clinical findings, laboratory and clinical findings related with MS, subjects having 0 to 4 MS criteria and MS patients according to the mFGS groups are seen in Table 2.

Table 2. Comparisons of subgroup percents and/or means of age, marital status, anthropometric values, associated clinical findings, laboratory and clinical findings related with MS, subjects having 0 to 4 MS criteria and MS patients according to the mFGS groups.

\begin{tabular}{|c|c|c|c|c|c|c|}
\hline Parameters & & \multicolumn{2}{|c|}{$\begin{array}{c}16-25 \text { mFGS } \\
n: 62\end{array}$} & \multicolumn{2}{|c|}{$\geq 26$ mFGS n:82 } & $\mathbf{p}$ \\
\hline \multirow[t]{2}{*}{ Mean Age } & & \multicolumn{2}{|c|}{$24.11 \pm 7.23$} & \multicolumn{2}{|c|}{$24.79 \pm 7.82$} & $0.595 \ddagger$ \\
\hline & 18-35 & 57 & $91.94 \%$ & 69 & $84.15 \%$ & \\
\hline \multirow{2}{*}{ Age groups } & $>35$ & 5 & $8.06 \%$ & 13 & $15.85 \%$ & $0.162 t$ \\
\hline & Unmarried & 47 & $75.81 \%$ & 51 & $62.20 \%$ & \\
\hline Marital status & Married & 15 & $24.19 \%$ & 31 & $37.80 \%$ & $0.083+$ \\
\hline Weight (Kg) & & \multicolumn{2}{|c|}{$55.51 \pm 8,08$} & \multicolumn{2}{|c|}{$75.54 \pm 16.69$} & $0.0001 \neq$ \\
\hline Height $(\mathrm{cm})$ & & \multicolumn{2}{|c|}{$159.61 \pm 6.02$} & \multicolumn{2}{|c|}{$160.27 \pm 5.18$} & $0.484 \ddagger$ \\
\hline \multirow[t]{4}{*}{ BMI } & & \multicolumn{2}{|c|}{$21.8 \pm 3.12$} & \multicolumn{2}{|c|}{$29.42 \pm 6.28$} & 0.0001* \\
\hline & $<18,5$ & 9 & $14.52 \%$ & 2 & $2.44 \%$ & \\
\hline & $18,5-24,9$ & 44 & $70.97 \%$ & 13 & $15.85 \%$ & \\
\hline & $25-29,9$ & 7 & $11.29 \%$ & 37 & $45.12 \%$ & \\
\hline \multirow[t]{3}{*}{ BMI groups } & $\geq \mathbf{3 0}$ & 2 & $3.23 \%$ & 30 & $36.59 \%$ & 0.0001 \\
\hline & Absent & 5 & $8.06 \%$ & 14 & $17.07 \%$ & \\
\hline & Present & 57 & $91.94 \%$ & 68 & $82.93 \%$ & $0.114 \%$ \\
\hline Acne & Absent & 5 & $8.06 \%$ & 8 & $9.76 \%$ & \\
\hline \multirow[t]{2}{*}{ Seborrhea } & Present & 57 & $91.94 \%$ & 74 & $90.24 \%$ & $0.726 \%$ \\
\hline & Absent & 1 & $1.61 \%$ & 1 & $1.22 \%$ & \\
\hline \multirow[t]{2}{*}{ AGA } & Present & 61 & $98.39 \%$ & 81 & $98.78 \%$ & $0.842 \ddagger$ \\
\hline & Absent & 59 & $95.16 \%$ & 76 & $92.68 \%$ & \\
\hline \multirow[t]{2}{*}{ Amenorrhea } & Present & 3 & $4.84 \%$ & 6 & $7.32 \%$ & $0.543 \$$ \\
\hline & Absent & 3 & $4.84 \%$ & 6 & $7.32 \%$ & \\
\hline Oligomenorrhea & Present & 59 & $95.16 \%$ & 76 & $92.68 \%$ & $0.543 \$$ \\
\hline \multirow[t]{2}{*}{ PCOS } & Present & 62 & $100.00 \%$ & 82 & $100.00 \%$ & - \\
\hline & Absent & 27 & $43.55 \%$ & 29 & $35.37 \%$ & \\
\hline \multirow[t]{3}{*}{ Acanthosis nigricans } & Present & 35 & $56.45 \%$ & 53 & $64.63 \%$ & $0.319 \ddagger$ \\
\hline & Absent & 48 & $77.42 \%$ & 57 & $69.51 \%$ & \\
\hline & Present & 14 & $22.58 \%$ & 25 & $30.49 \%$ & $0.291 \ddagger$ \\
\hline \multicolumn{2}{|l|}{ Mean Insulin } & \multicolumn{2}{|c|}{$11.08 \pm 4.87$} & \multicolumn{2}{|c|}{$12.67 \pm 5.22$} & 0.038* \\
\hline Mean HbA1C & & \multicolumn{2}{|c|}{$5.51 \pm 0.44$} & \multicolumn{2}{|c|}{$5.55 \pm 0.5$} & 0.605 \\
\hline \multicolumn{2}{|l|}{ Mean HOMA-IR } & \multicolumn{2}{|c|}{$2.57 \pm 1.22$} & & \pm 1.77 & 0.033* \\
\hline & $<2,5$ & 34 & $54.84 \%$ & 33 & $40.24 \%$ & \\
\hline HOMA-IR & $\geq 2,5$ & 28 & $45.16 \%$ & 49 & $59.76 \%$ & $0.082 \ddagger$ \\
\hline Mean Glucose & & & $9 \pm 9.15$ & & \pm 11.37 & 0.201 \\
\hline & $<110$ & 53 & $85.48 \%$ & 65 & $79.27 \%$ & \\
\hline Glucose & $\geq 110$ & 9 & $14.52 \%$ & 17 & $20.73 \%$ & $0.337 t$ \\
\hline
\end{tabular}




\begin{tabular}{|c|c|c|c|c|c|c|}
\hline \multirow[t]{2}{*}{ Mean HDL } & \multirow[b]{2}{*}{$<50$} & \multicolumn{2}{|c|}{$54.53 \pm 16.29$} & \multicolumn{2}{|c|}{$47.88 \pm 9.81$} & \multirow[t]{2}{*}{ 0.003* } \\
\hline & & 38 & $61.29 \%$ & 68 & $82.93 \%$ & \\
\hline HDL & $\geq \mathbf{5 0}$ & 24 & $38.71 \%$ & 14 & $17.07 \%$ & $0.004 \%$ \\
\hline \multicolumn{2}{|l|}{ MeanTriglyceride } & \multicolumn{2}{|c|}{$124.29 \pm 43.27$} & \multicolumn{2}{|c|}{$144.51 \pm 37.63$} & $0.003 *$ \\
\hline & $<150$ & 31 & $50.00 \%$ & 27 & $32.93 \%$ & \\
\hline Triglyceride & $\geq 150$ & 31 & $50.00 \%$ & 55 & $67.07 \%$ & $0.039 \ddagger$ \\
\hline \multirow[t]{2}{*}{ Mean WC } & & \multicolumn{2}{|c|}{$76.60 \pm 9.39$} & \multicolumn{2}{|c|}{$89.62 \pm 10.38$} & 0.0001* \\
\hline & $<\mathbf{8 0}$ & 60 & $96.77 \%$ & 21 & $25.61 \%$ & \\
\hline Waist (cm) & $\geq \mathbf{8 0}$ & 2 & $3.23 \%$ & 61 & $74.39 \%$ & $0.0001 \div$ \\
\hline \multirow[t]{2}{*}{ Mean SBP } & & \multicolumn{2}{|c|}{$124.08 \pm 4,22$} & \multicolumn{2}{|c|}{$137.79 \pm 5.19$} & $0.0001 \neq$ \\
\hline & $<\mathbf{1 3 0}$ & 60 & $96.77 \%$ & 2 & $2.44 \%$ & \\
\hline SBP & $\geq \mathbf{1 3 0}$ & 2 & $3.23 \%$ & 80 & $97.56 \%$ & $0.0001 \div$ \\
\hline \multicolumn{2}{|l|}{ Mean DBP } & \multicolumn{2}{|c|}{$70.29 \pm 5.07$} & \multicolumn{2}{|c|}{$77.57 \pm 6.87$} & $0.0001 \neq$ \\
\hline \multirow{6}{*}{ DBP } & $<85$ & 62 & $100.00 \%$ & 61 & $74.39 \%$ & \multirow[b]{2}{*}{$0.0001 \div$} \\
\hline & $\geq 85$ & 0 & $0.00 \%$ & 21 & $25.61 \%$ & \\
\hline & 0 & 6 & $9.68 \%$ & 6 & $7.32 \%$ & \\
\hline & 1 criterion & 47 & $75.81 \%$ & 14 & $17.07 \%$ & \\
\hline & 2 criteria & 8 & $12.90 \%$ & 36 & $43.90 \%$ & \\
\hline & 3 criteria & 1 & $1.61 \%$ & 23 & $28.05 \%$ & \\
\hline \multirow[t]{2}{*}{ MS criteria (count) } & 4 criteria & 0 & $0.00 \%$ & 3 & $3.66 \%$ & $0.0001 \div$ \\
\hline & MS (-) & 61 & $98.39 \%$ & 56 & $68,29 \%$ & \\
\hline MS & MS (+) & 1 & $1.61 \%$ & 26 & $31.71 \%$ & $0.0001+$ \\
\hline
\end{tabular}

‡ Independent-samples t-test, *Mann-Whitney $U$ test, $\$$ Chi-square test

Means of weight and BMI, and presence of overweight and obese persons in the severe-mFGS group was significantly higher than those with moderate-mFGS (each $\mathrm{p}=0.0001$ ). Significantly higher means of insulin $(\mathrm{p}=0.038)$, HOMA-IR $(\mathrm{p}=0.033)$, and triglyceride $(\mathrm{p}=0.003)$, and lower means of HDL $(\mathrm{p}=0.003)$ were obtained in the severe-mFGS group, and presence of $\mathrm{HDL}<50$, and triglyceride $\geq 150$ were also higher in the severe-mFGS group $(\mathrm{p}=0.004$ and $\mathrm{p}=0.039)$. Both presence of $\mathrm{WC} \geq 80$ and its means were higher in the group with higher mFGS (each $\mathrm{p}=0.0001$ ). Presence of higher SBP and DBPs, and their means were significantly higher in severe-mFGS group (each $\mathrm{p}=0.0001$ ). Having two, three and four MS criteria of subjects, and those who were diagnosed with MS were significantly higher in severe-HR group (each $\mathrm{p}=0.0001$ ). Comparison of the means of HRrelated laboratory tests and SAFTT values in each region according to the $\mathrm{mFGS}$ groups are shown in Table 3.

Table 3. Comparison of the mean values of HR-related laboratory tests, and SAFTTs in each periumbilical region according to the $\mathrm{mFGS}$ groups.

\begin{tabular}{lccc}
\hline \hline Parameters & $\mathbf{1 6 - 2 5}$ mFGS n:62 & $\geq 26$ mFGS n:82 & p \\
\hline DHEA-SO4 & $346.19 \pm 113.54$ & $389.17 \pm 145.33$ & $0.084^{*}$ \\
\hline FAI & $4.72 \pm 4.5$ & $6.75 \pm 5.34$ & $\mathbf{0 . 0 0 4} *$ \\
\hline Androstenedion & $1.13 \pm 0.65$ & $1.21 \pm 0.65$ & $0.468 \neq$ \\
\hline TT & $0.56 \pm 0.34$ & $0.72 \pm 0.46$ & $\mathbf{0 . 0 3 6} *$ \\
\hline FT & $1.42 \pm 0.66$ & $1.52 \pm 0.69$ & $0.479^{*}$ \\
\hline SHBG & $56.26 \pm 37.41$ & $44.68 \pm 29.44$ & $\mathbf{0 . 0 0 8} *$ \\
\hline 17-OH-PG & $0.38 \pm 0.13$ & $0.4 \pm 0.14$ & $0.451 \neq$ \\
\hline Prolactin & $17.39 \pm 4.66$ & $17.71 \pm 4.69$ & $0.653^{*}$ \\
\hline SAFTT-Right & $23.89 \pm 7.87$ & $36.34 \pm 10.7$ & $\mathbf{0 . 0 0 0 1} \neq$ \\
\hline SAFTT-Left & $24.05 \pm 7.49$ & $36.61 \pm 10.55$ & $\mathbf{0 . 0 0 0 1} \neq$ \\
\hline SAFTT- Upper & $26.51 \pm 7.23$ & $38.97 \pm 10.44$ & $\mathbf{0 . 0 0 0 1} \neq$ \\
\hline SAFTT-Lower & $27.02 \pm 7.25$ & $39.34 \pm 10.37$ & $\mathbf{0 . 0 0 0 1} \neq$ \\
\hline \hline
\end{tabular}


According to the 17-OH-PG values, non of the patient had congenital adrenal hyperplasia. Most of FAI values $(n=116,80.56 \%)$ were below the cut-off value of FAI, and there was no significant difference between the moderate and severe-HR groups regarding the presence of FAI values $\geq 5$ $(12.90 \%$ versus $24.39 \%$ respectively) $(\mathrm{p}=0.085)$. However, significant differences were detected in

\section{DISCUSSION}

HR is a male pattern excessive terminal hair growth, which affects approximately 5-10 \% of women. Hirsute women usually demostrate 70 $80 \%$ androgen excessiveness, whereas approximately $5-15 \%$ of them do not show any androgen imbalance ${ }^{9,17}$. It is thought that idiopatic HR results from abnormal/increased sensitivity of hair follicles to normal levels of circulating androgens, especially in non-obese persons as associated with abdominal (android) obesity ${ }^{9,18}$. Because nearly $50 \%$ of the circulating testosterone is derived from peripheral tissues like adipose tissue with the enzymatic conversion of androstenedion in premenopausal women, it is thought that HR must be more common in overweight people ${ }^{17}$. Our all subjects were also premenopausal women, and most of them were owerveight and obese persons. Hyperandrogeniclinked clinical conditions, which are also IRrelated conditions have been described as HR, seborrhea, acne, AGA, AN, skin tag, oligo and amenorrhea 9,17,19. These conditions are usually accompanied by PCOS, which is the most common cause of oligo or anovulatory HR [4,9,19]. All of our subjects had PCOS. Patients with PCOS may have acne up to rate of $70 \%$, and oligo or amenorrhea may accompany to them, with a predominancy of oligomenorrhea $4,9,17,20$. Skin tag is frequently seen in AN patients, who can also have PCOS, obesity, MS or impairment of carbohydrate metabolism. AGA and IR/hyperinsulinemia relationship is strongly supported by Matilainen et al. and Bakry et al. They suggested that early onset AGA $(<35)$ could be a clinical marker of IR, and these cases should be assessed for MS components and IR. The role of insulin in hyperandrogenic skin findings of obese females has been explained with $5 \alpha$ reductase-induction, increased androgen receptor signal transduction, induction of sebum secretion and lipogenesis and keratinocyte-proliferation, by decreased levels of insulin-like growth factor (IGF) receptors and increased local levels of free IGF-1 ${ }^{9,19}$. Our findings were in agreement with above information. Except for the relatively low
FAI, TT and SHBG means between the groups with the dominance of first two values, and low values of the third in severe-mFGS group ( $\mathrm{p}=0.004,0.036$, and 0.008, respectively). Each SAFTT mean was significantly higher in the severe-score group (each $\mathrm{p}=0.0001$ ), independent of measurement sites.

rates of skin tag (27.08\%) and amenorrhea (6.25\%), all the subjects had PCOS, and most of them had the other mentioned androgen-related conditions with no significant differences between the mFGS groups. IR-related thoughts on the etiopathogenesis of HR have gradually been increased in recent years, and hyperinsulinaemic androgen excess was accepted the most common cause of especially idiopathic HR ${ }^{19,21}$. Many studies showed that impaired glucose tolerance and IR may seen in hirsute women with or without PCOS 9,19. Hyperinsulinemia and increased IR are accepted as not only the most important cause, but also concequences of obesity and MS, as well. It is suggested that increased insulin leads to gonadotropin-like stimulation on IGF-1 receptors in ovarian techa cells, and results increased androgen production ${ }^{9,17,19}$. BMI is the most commonly used method in estimating of obesity, whereas circulating androgens are positively correlated with increased BMI in HR. However, the correlation may not always be valid, and may change depending on the racial/ethnic characteristics of persons. Naeini et al reported significantly higher BMI rates in young Iranian hirsute women compare to healty ones ${ }^{17}$. Douchi et al. showed significantly higher BMI and upperhalf body type obesity in PCOS women with or without HR than controls ${ }^{22}$. Also, Borcha et al. reported a positive correlation between hiperandrogenemia and BMI/visceral obesity ${ }^{23}$. Although our overweight/obese subjects had slight majority over others $(52.78 \%$ versus $47.22 \%$ ), significantly higher BMIs were detected in severe-mFGS group. In women with severe IRsyndromes, hyperandrogenemia and PCOS are common findings. Moreover, HR and oligomenorrhea were shown to be the referring signs in several cases of severe IR-syndromes like MS ${ }^{24}$. Sally et al. recommended that patients with HR and especially ones also having PCOS should be evaluated for MS parameters such as BMI, WC, high BP, impaired glucose tolerance and lipid profiles ${ }^{25}$. However, the delevelopment of MS is depended on the etiology of HR, with higher risk for persons with classic PCOS followed by those with ovulatory PCOS and idiopathic hyperandrogenism, and the lowest risk 
for women with idiopathic HR ${ }^{9}$. Because all of our subjects had oligo or anovulatory PCOS, they were high risk group for MS. However, according to ATP III criteria, above threshold insulin and glucose levels were detected in only rates of $0.02 \%$ and $18.06 \%$. Mean insulin values were significantly higher in severe-mFGS group, whereas mean glucose was not different. HOMAIR is one of the tests used for quantifying IR. Its value $\geq 2.5$ is taken as an indicator for IR in adults 15. We also detected increased HOMA-IR in $53.47 \%$ of total of subjects, in which mean values were significantly higher in severe-mFGS group. Previous reports on relationship between HR and IR give contradictory results in PCOS patients ${ }^{26}$. Because our all subjects had PCOS, but only severe-mFGS group had significantly higher BMIs, the relationship between IR and HR appears to be associated with more severe obesity, independently of PCOS. Indeed, a great majority of our subjects had above thresholds values for low-HDL, high-trygliceride, SBP, DBP and WC, and there were significant differences in terms of MS parameters between the groups, favoring severe-mFGS group. Even if HR had previously been associated with hyperandrogenemia, there is a poor correlation between the severity of HR and excess of androgens. Especially idiopatic HR does not correlate well with amount of androgens. For determining of androgens in HR, most used tests are TT, FT, DHEAS, androstenedion, SHBG, 17OH-PG and prolactin ${ }^{9,27}$. Because the difficulties in sensitive determining of FT values, use of FAI index is suggested, and it is accepted as better predictor for hyperandrogenism than testosterone 27. On the other hand, importance of serum androstenedione and DHEAS in HR diagnosis is unclear, and DHEAS levels may not always reflect the adrenocortical steroidogenesis 9 . Although TT means of all subjects were within the normal limits, and FAI values were subthreshold $(<5)$ in most subjects, significantly higher values of TT, and significantly different and above threshold FAI means were obtained in severe-mFGS group. From the other side, because high insulin decreases SHBG production in the liver, FT levels increase in plasma ${ }^{17}$. Although SHBG levels of all subjects were within the reference ranges, means of severe-mFGS group were significantly lower. Because oligo/anovulatory PCOS is usually associated with high androgen levels ${ }^{4,9,20}$, and our androgen levels were different but below threshold values, different degrees of HR in our subjects might be associated with the differences in IR-related parameters such as BMI, insulin and HOMA-IR. Our results supported the previous reports regarding to have high androgens is not necessary for the development of HR. They also support that subtreshold androgen levels may be enough for excessive stimulation of hair follicles, because MS-related hyperinsulinemic factors provide a susceptibility to the androgens with the help of suppressed SHBG levels in obese women. On the other hand, USG-determined SAFTT measurement is a simple and important method to evaluate the association between BMI/abdominal obesity and MS ${ }^{28 .}$ There is some reports supporting presence of higher SAFTT values in women with PCOS ${ }^{16,29}$. Wehr et al. showed that increased lower-abdomen and upper-back SAFTTs are associated with IR, impaired glucose tolerance, and an unfavorable lipid profile in these women ${ }^{29}$. However, no study was reported in association between SAFTT and mFGSs. We obtained significantly high values in SAFTT means at each periumblical region, in severemFGS group. Presented findings indicate that increased SAFTT may be a metabotrophic indicator for severity of $\mathrm{HR}$ in especially overweight women by creating more androgenproducing areas, as considered in MS and PCOS cases. Because presented study was not controlled and all the subjects had PCOS, we do not yet know whether there is a cutt-off value for SAFTT to be used as an indicator for HR cases, independently of PCOS. Additionally, although relatively small number of subjects and unequal numbers of groups limit our conclusions, because MS were detected 26 times more in severe-MFS group, we also think that HR may be considered as an additional criterion of MS, in especially obese women. Nevertheless, controlled and broadbased further studies are needed to support our results.

\section{CONCLUSION}

Women with severe hirsutism are more likely to have a thicker SAFT and also metabolic syndrome than those with lower scores. Thickened SAFT may a simple metabotrophic indicator for preliminary assessment of severity of HR by creating more androgen-producing areas.

\section{REFERENCES}

1. Reference 1- Klein J, Permana PA, Owecki M, et al. What are subcutaneous adipocytes really good for? Exp Dermatol 2007;16:45-70. PMID: 17181636

2. Reference 2- Chaldakov GN, Fiore M, Tonchev AB, et al. Homo obesus: a 
metabotrophin-deficient species. Pharmacology and nutrition insight. Curr Pharm Des 2007;13:2176-9. PMID: 17627549

3. Reference 3- Ibáñez L, Diaz M, Sebastiani G, et al. Treatment of androgen excess in adolescent girls: ethinylestradiol cyproteroneacetate versus low-dose pioglitazone-flutamide-metformin. J Clin Endocrinol Metab 2011;96:3361-6. PMID: 21865363

4. Reference 4- Revised 2003 consensus on diagnostic criteria and long-term health risks related to polycystic ovary syndrome (PCOS). Human Reprod 2004;19:41-7. PMID: 14688154

5. Reference 5- Appropriate body-mass index for Asian populations and its implications for policy and intervention strategies". WHO Expert Consultation. The Lancet 2004;363:157-63. PMID: 14726171

6. Reference 6- Obesity: preventing and managing the global epidemic. Report of a WHO consultation. World Health Organ Tech Rep Ser 2000; 894:i-xii, 1-253. PMID: 11234459

7. Reference 7- Alderman MH. JNC 7: brief summary and critique. Clin Exp Hypertens 2004;26:753-61. PMID: 15702631

8. Reference 8- Coskun A, Ercan O, Arikan DC,et al. Eur J Obstet Gynecol Reprod Biol 2011;154:167-71. PMID: 21041013

9. Reference 9- Escobar-Morreale HF, Carmina E, Dewailly D, et al. Epidemiology, diagnosis and management of hirsutism: a consensus statement by the androgen excess and polycystic ovary syndrome society. Hum Reprod Update 2012;18:146-70. PMID: 22064667

10. Reference 10- Clearfield M, Pearce M, Nibbe Y, Crotty D, Wagner A. The "New Deadly Quartet" for cardiovascular disease in the 21st century: obesity, metabolic syndrome, inflammation and climate change: how does statin therapy fit into this equation? Curr Atheroscler Rep 2014;16:380. PMID: 24338517

11. Reference 11- Executive summary of the third report of the National Cholesterol Education Program (NCEP) expert panel on detection, evaluation, and treatment of high blood cholesterol in adults (Adult Treatment Panel III) JAMA 2001;285:2486-97. PMID: 11368702
12. Reference 12- Carter GD, Holland SM, Alaghband-Zadeh J,et al. Investigation of hirsutism: testosterone is not enough. Ann Clin Biochem 1983;20:262-3. PMID: 6685986

13. Reference 13- Blume-Peytavi U, Blumeyer A, Tosti A,et al; European Consensus Group. S1 guideline for diagnostic evaluation in androgenetic alopecia in men, women and adolescents. Br J Dermatol 2011;164:5-15. PMID: 20795997

14. Refernce 14- Matthews D, Hosker J, Rudenski A, et al. Homeostasis model assessment: insulin resistance and $\beta$-cell function from fasting plasma glucose and insulin concentrations in man. Diabetologia 1985;28: 412-9. PMID: 3899825

15. Reference 15- Singh Y, Garg MK, Tandon N, Marwaha RK. A Study of Insulin Resistance by HOMA-IR and its Cut-off Value to Identify Metabolic Syndrome in Urban Indian Adolescents. Clin Res Pediatr Endocrinol 2013;5:24551. PMID: 24379034

16. Reference 16- Bertoli S, Leone A, Vignati $\mathrm{L}$, et al. Metabolic correlates of subcutaneous and visceral abdominal fat measured by ultrasonography: a comparison with waist circumference. Nutr J 2016;15:2. PMID: 26732788

17. Reference 17- Naeini F, Najafian J, Jazebi N. Hirsutism and body mass index in a representative sample of Iranian people. ARYA Atheroscler 2012;8:43-54. PMID: 23056100

18. Reference 18- Reingold SB, Rosenfield RL. The relationship of mild hirsutism or acne in women to androgens. ArchDermatol 1987;123:209-12. PMID: 2949707

19. Reference 19- Napolitano M, Megna M, Monfrecola G. Insulin Resistance and Skin Diseases.Scientific WorldJournal 2015;2015:479354. PMID: 25977937

20. Reference 20- Broekmans FJ, Knauff EA, Valkenburg O, et al. PCOS according to the Rotterdam consensus criteria: change in prevalence among WHO-II anovulation and association with metabolic factors. BJOG 2006;113:1210-7. PMID: 16972863

21. Reference 21- Ibáñez L, Díaz M, Sebastiani G, et al. Oral contraception vs insulin sensitization for 18 months in nonobese adolescents with androgen 
excess: posttreatment differences in $\mathrm{C}$ reactive protein, intima-media thickness, visceral adiposity, insulin sensitivity, and menstrual regularity. J Clin Endocrinol Metab 2013;98:E902-7. PMID: 23547047

22. Reference 22- Douchi T, Ijuin $H$, Nakamura S, et al. Body fat distribution in women with polycystic ovary syndrome. Obstet Gynecol 1995;86:5169. PMID: 7675372

23. Reference 23- Bochra F, Mélika C, Myrvat K,et al. Role of visceral obesity in metabolic disorders associated with hyperandrogenia in hirsute women. Tunis Med. 2005;83:532-6. PMID: 16383198

24. Reference 24- Vigouroux C. What have we learned form monogenic forms of severe insulin resistance associated with PCOS/HAIRAN? Ann Endocrinol (Paris) 2010;71:222-4. PMID: 20362964

25. Reference 25- Salley KE, Wickham EP, Cheang KI, et al. Glucose intolerance in polycystic ovary syndrome - a position statement of the Androgen Excess Society. J Clin Endocrinol Metab 2007;92:4546-56. PMID: 18056778

26. Reference 26- Panidis D, Tziomalos K, Papadakis E, et al. The clinical significance and primary determinants of hirsutism in patients with polycystic ovary syndrome. Eur J Endocrinol 2013;168:871-7. PMID: 23557988

27. Reference 27- Al Kindi MK, Al Essry FS, Al Essry FS, Mula-Abed WA. Validity of serum testosterone, free androgen index, and calculated free testosterone in women with suspected hyperandrogenism. Oman Med J 2012;27:471-4.

28. Reference 28- Shojaei MH, Shirani S, Eshraghian MR, Soleymanzadeh M. Sonographic prediction of body fat volume (subcutaneous and visceral fat) in cardiovascular patients. J Tehran Heart Cent 2010;5:83-6. PMID: 23074573

29. Reference 29- Wehr E, Möller R, Horejsi $\mathrm{R}$, et al. Subcutaneous adipose tissue topography and metabolic disturbances in polycystic ovary syndrome. Wien Klin Wochenschr 2009;121:262-9. PMID: 19562283 